\title{
Study of Genetic Variability of Palmyapalm on the Basis of Tree Morphology and Yield Parameters in Bihar
}

\author{
Soni Kumari ${ }^{1}$, Ruby Rani ${ }^{1 *}$, Samik Sengupta ${ }^{1}$, AhmarAftab ${ }^{2}$, \\ Neha Kumari ${ }^{1}$ and Ankita Aman ${ }^{1}$ \\ ${ }^{1}$ Department of Horticulture (Fruit and Fruit Technology), ${ }^{2}$ Department of Food Science \\ and Post-Harvest Technology, Bihar Agricultural University, Sabour, \\ Bhagalpur, Bihar, India-813210 \\ *Corresponding author
}

\section{A B S T R A C T}

\begin{tabular}{|l|}
\hline Ke y w o r d s \\
Palmyra, \\
Variability, \\
Morphology, Yield \\
\hline Article Info \\
\hline $\begin{array}{l}\text { Accepted: } \\
18 \text { April } 2020 \\
\text { Available Online: } \\
10 \text { May } 2020\end{array}$ \\
\hline
\end{tabular}

Palmyra palm (Borassus flabelliferL ) or commonly called Taad or Tarh is a palm tree of the Sugar palm group. It is an important multipurpose tree of great utility. There is a rich genetic diversity of palmyrah in Bihar, but no database is available regarding Palmyra. Thus a study was undertaken to study the variability in Palmyra for their plant morphological traits and yield parameters. Sample was collected during fruiting season and plants with diverse in nature for tree characteristics and fruit yield. Among 22 genotypes selected in the area surveyed, the great variability was noted with respect to plant height (dwarf and Tall) and yield parameters. The average height of the palms was $15.22 \mathrm{~m}$ with a variation from $7.10 \mathrm{~m}$ in PC-7 to $22.50 \mathrm{~m}$ in PC-12.Trunk girth varied from $137 \mathrm{~cm}$ (PC-11) to $180 \mathrm{~cm}(\mathrm{PC}-6)$ and . Bunch number ranged from $7 \mathrm{bunch} /$ tree to 34 bunches/tree in with yield variation from 84 fruit /palm to480 fruits. Grfeat variations in leaf parameters were also observed.

\section{Introduction}

Palmyra Palm (Borassus spp.) belongs to family Arecaceae and order Arecales. It is also called fan palm due to its typical palm shaped leaves. The genus Borassus constituted of five species. These species have different centre of origin. The species are
Borassus aethiopum, Borassus akcassii. Borassus flabellifer, Borassus heineansus and B. madagascariensis.

Among all these species Borassus flabellifer L. or Asian palm is of most important which has great economic use. The word "Borassus" is derived from a Greek word means "leathery 
covering of fruits" and "flabellifer" means "fan bearing" (Small, 2012)It is also known Tarh ,Taad, Toddy Palm, Sugar Palm and its fruit is known as Tari in Hindi, Munjal in Urdu, Taadfali in Gujarati and Sometimes known as Ice-apple in British English especially by the immigrants living in India Archeological and historical evidence indicated the presence this species in S.E. Asia at least 1500 years ago.

In India the wealth of Palmyra palm is very rich with a population nearly 122 million palms (Vengaiah, et al., 2012)and half of them are in Tamil Nadu. More than $50 \%$ of palms are concentrated in the southern district of Thoothukudi (AICRP, Palms, 2015). The state of Bihar has very rich diversity ofpalmyra with more than 92 lakh palmyra population in the state. Districts like Gaya, Jahanabad, Nalanda, Banka and Bhagalpur are the leading districts of Bihar with large palmyra population. It is easily grown without much care and can be spotted growing in wild, in agricultural fields and sporadically even on wastelands as stray plantation.

Palmyra palm is a versatile tree of immense use to mankind of which no part is wasted. Palmyra is a dioecious palm with the great majority of its economic products such as immature endosperm, mesocarp pulp, fibre from the fruits and tuberous seedlings are obtained only from female palms.

Palmyra is means of livelihood of many people in the state especially who comes from economically and socially weaker section. Thus it is essential to exploit the availability of large palmyra population in the state. Unfortunately no data base regarding their variability is available till date. Thus attempts were made to study the variability in palmyra on the basis of their plant morphology and yield potential.

\section{Materials and Methods}

To study the variability in palmyra a survey of Palmyra palm plants was conducted during fruiting season in Bhagalpur district and its adjoining area in Bihar. Survey was conducted in five blocks of the district i.e Sabour, Kahalgaon, Nathnagar, Jagdishpur, Goradih .The sample was collected during survey on the basis of tree height, fruit size and yield potential by visual observation of palm during maturity period in the month of August, 2017 to study the variability. Observations were taken on tree characteristics and yield potential. Altogether 22 genotypes of palmyra were selected from the area surveyed and given number such as PC-1 (Palmyra collection -1) to PC- 22 (Palmyra collection 22). Observations on tree morphology such as tree height, girth, number of leaf scarce, leaf characteristics and yield parameters were taken to study the variability.

Tree height of different genotypes of palm was measured by using measuring tape from the crown to the base of the palm and expressed in meter. Trunk circumference was measured at $1 \mathrm{~m}$ height from the base of the palm and expressed in centimeter by using measuring tape. Number of leaf scars was counted in $50 \mathrm{~cm}$ length on trunk above $1 \mathrm{~m}$ of the base of the trunk. Approximate age of palm was measure in years with the help of owner of that particular palm.

Total number of fruits at maturity period of selected palm was counted in all the bunch and average was calculated by dividing total number of fruits by number of bunch in that tree.

During the survey numbers of total bunch were counted in selected palm. Number of fruits/palm was taken by adding all the fruits in all the bunch of that tree. Among leaf parameters total number of leaves/tree, 
number of leaflets /leaf was counted in the entire selected palm during survey. The length of the leaves was measured with the help of measuring tape and expressed in centimeters from the portion of leaflet bearing area.. The length of petiole was taken from the base of leaf to the leaflet bearing portion. Among yield parameters number of bunch per palm and number of fruits per bunch was counted and yield per plant was calculated in terms of no of fruit per palm.

\section{Results and Discussion}

The characteristics feature of Palmyra tree such as age of the palm, plant height, trunk girth at $1 \mathrm{~m}$ height and number of leaf scarce in $50 \mathrm{~cm}$ of trunk length was studied in different germplasm of Palmyra and data is presented in Table 1. Significant variation was observed with respect to these parameters among the germplasm collected. The age of the palms varied from 30 years in PC-1 to 45 years in PC-18 with mean age of 36.35years. Similar type of variation $\mathrm{n}$ plant height and age of the flowering palm has been reported by Sankarangam et al., (1999). It has been reported that slow growing Palmyra commences flowering only after 12-15 years of maturity (Ponnuswami, 2010) and sometimes it takes about 20 years to mature as reported by Pipatchartlearnwong et al., (2017). Palmyra is robust and long lived palm that can survive up to 100years (Sankaralingam et al., 1999). The average height of the palms under study was $15.22 \mathrm{~m}$ with a variation from $7.10 \mathrm{~m}$ in $\mathrm{PC}-7$ to $22.50 \mathrm{~m}$ in PC-12.Variation in plant height of Palmyra from 15 to $20 \mathrm{~m}$ has been enunciated by Bhaskar (2017) in Nellore district of Andhra Pradeshhas reported a Height up to 30 $\mathrm{m}$ of single stem robust Palmyra has also been reported (Kovoor, 1983).

Very high variation in trunk girth and in number of scars in $50 \mathrm{~cm}$ trunk length above
$1 \mathrm{~m}$ plant height of trunk among the collected genotypes was noticed. Trunk girth varied from $137 \mathrm{~cm}$ (PC-11) to $180 \mathrm{~cm}$ (PC-6) having mean value of $159.09 \mathrm{~cm}$. Variation in number of scarce was from 12(PC-1) 20(PC-18). Variation in trunk circumferences of $1.5 \mathrm{~m}$ to $3.0 \mathrm{~m}$ at the base has been reported by Bhaskar(2017) in Nellore district of Andhra Pradesh and $1.7 \mathrm{~m}$ and trunk diameter of 60-90 cm (Sankaralingam et al., 1999).

The data on different parameters of Palmyra leaf such as number of leaves/plant, number of leaflets/leaf, petiole length, petiole girth and leaf length was recorded in all the germplasm and analyzed data has been depicted in Table 2. The close perusal of data showed high variation in all these parameters among the genotypes of Palmyra. The findings of present investigation showed variation in leaf characters such as length of leaf and petiole, number of leaflets and number of leaves per palm among the genotype studied.

Total number of leaflets/leaf was found highly variable, which is varied from 82 (PC$20)$ to $107(\mathrm{PC}-21)$. The mean value of leaflets/leaf was noted 92.68. Higher number of leaflets/leaf was noted in PC-19, PC-18, PC-22, PC-10 and PC-2 genotypes with 105,103, 98, 98 and 97 number of leaflets/leaf and less no of leaflets/leaf was noted in PC11, PC-17, PC-4, PC-12 genotypes with leaflet number of $85,86,87$ and 87 , respectively. The variation in leaf length varied from $111 \mathrm{~cm}$ (PC5) to $145 \mathrm{~cm}$ (PC3) having mean value $125.27 \mathrm{~cm}$. The genotypes having higher leaf length of $143 \mathrm{~cm}, 142 \mathrm{~cm}$, $141 \mathrm{~cm}$ and $140 \mathrm{~cm}$ was observed in PC-12, PC-8, PC-15 and PC-19 respectively. Variation in leaf number from 20-30 per palm has been reported (Sankaralingam et al., 1999; Kovoor, 1983) and 25-40 leaves (Morton, 1988) in palmyra earlier. .Leaf length of $0.60 \mathrm{~m}$ to $1.2 \mathrm{~m}$ has also been 
enunciated in past (Bhaskar, 2017) 2-4 $\mathrm{ft}$ (Morton, 1988) and 1.0 to $1.5 \mathrm{~m}$ by Sankaralingam et al., (1999). Whereas 1-2 m leaf length in palmyra has been found by Bhaskar (2017). Variation in number of leaf lets and petiole length has been enunciated by earlier workers from different place of India and abroad (AICRP, Palms, 2015; Morton, 1988].

\section{Yield parameters}

Yield parameters like number of fruiting bunch and number of fruits/bunch was recorded in each of the genotypes collected and yield/palm. The data collected were analysed statistically and depicted in Table 3. Diversity with respect to yield parameters like number of bunch/ palm, number of fruits / bunch consequently fruit yield / palm was found during the present investigation. Variation with respect to number of bunch/ tree among different genotypes of Palmyra was recorded. The variation was from 7 bunch/tree in PC-6 to 34 bunches/tree in PC14. The mean value of bunch number/tree was recorded 18.73 .

Table.1 Tree characteristics of different genotypes of Palmyra palm

\begin{tabular}{|c|c|c|c|c|}
\hline Genotypes & $\begin{array}{c}\text { Age of tree } \\
(\text { yrs })\end{array}$ & $\begin{array}{l}\text { Plant height } \\
(\mathbf{m})\end{array}$ & $\begin{array}{l}\text { No of scars } / 50 \mathrm{~cm} \text { of } \\
\text { trunk length }\end{array}$ & Trunk girth $(\mathrm{cm})$ \\
\hline PC1 & 30 & 15 & 12 & 150 \\
\hline PC2 & 32 & 12.2 & 16 & 142 \\
\hline PC3 & 35 & 15.54 & 18 & 160 \\
\hline PC4 & 40 & 9.24 & 20 & 162 \\
\hline PC5 & 37 & 11.1 & 18 & 165 \\
\hline PC6 & 31 & 12.1 & 15 & 180 \\
\hline PC7 & 36 & 7.1 & 15 & 172 \\
\hline PC8 & 41 & 13.08 & 17 & 145 \\
\hline PC9 & 38 & 16.87 & 15 & 152 \\
\hline PC10 & 32 & 13.55 & 13 & 157 \\
\hline PC11 & 38 & 14.2 & 17 & 137 \\
\hline PC12 & 43 & 20.2 & 14 & 149 \\
\hline PC13 & 40 & 22.5 & 13 & 162 \\
\hline PC14 & 36 & 18.25 & 13 & 172 \\
\hline PC15 & 32 & 18.75 & 16 & 177 \\
\hline PC16 & 43 & 14 & 16 & 167 \\
\hline PC17 & 41 & 16.75 & 19 & 143 \\
\hline PC18 & 45 & 13.45 & 20 & 148 \\
\hline PC19 & 36 & 18.5 & 18 & 145 \\
\hline PC20 & 32 & 18.25 & 17 & 164 \\
\hline PC21 & 37 & 19.75 & 15 & 178 \\
\hline PC22 & 38 & 14.55 & 17 & 173 \\
\hline Mean & 36.95 & 15.22 & 16.09 & 159.09 \\
\hline Range & $30-45$ & $7.10-22.50$ & $12-20$ & $137-180$ \\
\hline $\operatorname{SEm}( \pm)$ & 2.25 & 0.80 & 0.48 & 2.78 \\
\hline $\operatorname{CV}(\%)$ & 7.30 & 24.66 & 14.08 & 8.20 \\
\hline
\end{tabular}


Int.J.Curr.Microbiol.App.Sci (2020) 9(5): 2522-2528.

Table.2 Leaf characteristics of different genotypes of Palmyra palm

\begin{tabular}{|c|c|c|c|c|c|}
\hline Genotypes & $\begin{array}{c}\text { No of } \\
\text { leaves/tree }\end{array}$ & $\begin{array}{c}\text { No of } \\
\text { leaflets/leaf }\end{array}$ & $\begin{array}{l}\text { Leaf length } \\
\text { (cm) }\end{array}$ & $\begin{array}{c}\text { Petiole } \\
\text { length }(\mathbf{c m})\end{array}$ & $\begin{array}{c}\text { Girth of } \\
\text { petiole }(\mathbf{c m})\end{array}$ \\
\hline PC1 & 9 & 92 & 140 & 120 & 21 \\
\hline PC2 & 12 & 97 & 132 & 140 & 25 \\
\hline PC3 & 34 & 95 & 145 & 118 & 18 \\
\hline PC4 & 22 & 87 & 123 & 106 & 23 \\
\hline PC5 & 21 & 89 & 111 & 144 & 25 \\
\hline PC6 & 24 & 93 & 133 & 109 & 19 \\
\hline PC7 & 29 & 90 & 127 & 152 & 21 \\
\hline PC8 & 26 & 89 & 142 & 155 & 21 \\
\hline PC9 & 35 & 88 & 125 & 145 & 20 \\
\hline PC10 & 20 & 98 & 134 & 123 & 18 \\
\hline PC11 & 21 & 85 & 136 & 122 & 25 \\
\hline PC12 & 25 & 87 & 143 & 124 & 17 \\
\hline PC13 & 18 & 97 & 126 & 116 & 21 \\
\hline PC14 & 32 & 92 & 117 & 128 & 23 \\
\hline PC15 & 22 & 90 & 141 & 132 & 21 \\
\hline PC16 & 19 & 89 & 133 & 138 & 20 \\
\hline PC17 & 23 & 86 & 125 & 155 & 19 \\
\hline PC18 & 18 & 103 & 131 & 145 & 16 \\
\hline PC19 & 15 & 105 & 140 & 108 & 23 \\
\hline PC20 & 17 & 82 & 123 & 115 & 22 \\
\hline PC21 & 23 & 107 & 134 & 125 & 21 \\
\hline PC22 & 21 & 98 & 135 & 142 & 21 \\
\hline Mean & 22.09 & 92.68 & 125.27 & 130.09 & 20.90 \\
\hline Range & 9-35 & $82-107$ & 111-145 & 106-155 & $16-25$ \\
\hline $\operatorname{SEm}( \pm)$ & 1.38 & 1.41 & 3.12 & 3.30 & 2.20 \\
\hline $\mathrm{CV}(\%)$ & 29.37 & 7.15 & 11.30 & 11.90 & 8.35 \\
\hline
\end{tabular}


Int.J.Curr.Microbiol.App.Sci (2020) 9(5): 2522-2528.

Table.3 Yield parameters of different genotypes of Palmyra palm

\begin{tabular}{|c|c|c|c|}
\hline Genotypes & No of bunch/tree & No of fruits/bunch & No of fruits/palm \\
\hline PC1 & 9 & 12 & 108 \\
\hline PC2 & 15 & 16 & 240 \\
\hline PC3 & 32 & 11 & 352 \\
\hline PC4 & 9 & 13 & 117 \\
\hline PC5 & 12 & 9 & 108 \\
\hline PC6 & 7 & 14 & 98 \\
\hline PC7 & 7 & 12 & 84 \\
\hline PC8 & 23 & 11 & 253 \\
\hline PC9 & 21 & 7 & 147 \\
\hline PC10 & 24 & 8 & 192 \\
\hline PC11 & 30 & 16 & 480 \\
\hline PC12 & 34 & 11 & 374 \\
\hline PC13 & 11 & 9 & 99 \\
\hline PC14 & 15 & 15 & 225 \\
\hline PC15 & 23 & 13 & 299 \\
\hline PC16 & 17 & 11 & 187 \\
\hline PC17 & 8 & 12 & 96 \\
\hline PC18 & 14 & 9 & 126 \\
\hline PC19 & 30 & 13 & 390 \\
\hline PC20 & 28 & 13 & 364 \\
\hline PC21 & 25 & 9 & 225 \\
\hline PC22 & 18 & 14 & 252 \\
\hline Mean & $\mathbf{1 8 . 7 3}$ & $\mathbf{1 1 . 7 3}$ & $\mathbf{1 5 9 . 0 9}$ \\
\hline Range & $\mathbf{7 - 3 4}$ & $\mathbf{7 - 1 6}$ & $\mathbf{8 4}-\mathbf{4 8 0}$ \\
\hline SEm( $)$ & $\mathbf{1 . 8 6}$ & $\mathbf{0 . 5 3}$ & $\mathbf{2 . 7 8}$ \\
\hline CV(\%) & $\mathbf{4 6 . 5 0}$ & $\mathbf{2 1 . 4 0}$ & $\mathbf{8 . 2 0}$ \\
\hline & & & \\
\hline & & & \\
\hline & & & \\
\hline
\end{tabular}

The genotypes with higher number of bunch were PC-3, PC-19, PC-20 and PC-21 having 32, 30, 28 and 25 bunches/tree, respectively. The less number of bunches/tree of 8,9,11 bunches were noted in PC-7, PC-9 and PC-17. Variation in number of fruits/bunch was from 7(PC9) to 16 (PC-11). Diversity in yield parameters of palmyra has also been reported by Morton (1988). The next genotype having higher no of fruits/bunch was recorded in PC14(15), PC-22(14), PC-4, and PC-15 (13).An average crop of $B$. flabellifer in Ceylon had
350 fruits (Kovoor, 1983). Usually a single tree produced anywhere between 50 to 300 fruits in Nellore district of Andhra Pradesh (Bhaskar, 2017).

Thus great variation in tree morphology and yield potential was observed in palmyra in the area surveyed under Bhagalpur district and its adjoining part. A strong data base is needed to be collected for palmyra in orser to exploit this crop at commercial scale. 


\section{References}

AICRP, Palms, 2015. Annual report. All India coordinated research project on palms , CPCRI, Kasaragod, India, pp 72-73

Bhaskar, K. 2017. India Borassus flabellifer L. A tree behind the forest with multiple uses in rural areas: A case study from Nellore district, Andhra Pradesh, India. Imp. J. Interdiscip. Res. 3(5):1486.

Kovoor, A. 1983. The Palmyrah Palm potential and perspectives FAO Plant Production and Protection paper, FAO, Rome

Pipatchartlearnwong K, Akarapong S, Supachai V and Somsak A. 2017. Genetic evidence of multiple invasions and a small number of founders of Asian Palmyra palm (Borassus flabellifer) in Thailand.BMC Genetics, 18:88

Morton F. Julia. 1988. Noteson Distribution, Propagation and Products of Borassus
Palms (Arecaceae). Economic Botany, 42(3), 1988, pp. 420-441.

Ponnuswami V. 2010.Genetic diversity in Palmyrah genotype using morphological and molecular markers. Electronic Journal of plant breeding, 1(4): 556-567.

Sankaralingam A., Hemalatha G. And Ali A.M. (1999). A Treatise on Palmyra (H Hameed Khan, ed), All- India Coordinated Research project on Palms, Agriculture College and Research Institute, TNAU, Killikulam, Tamil Nadu, India,: 1-40.

Small, E . 2012. Top Hundred Exotic Fruit Plant. Taylor and Francis, CRC Press, 20129443

Vengaiah P.C., Murthy G.N., Prasad K. R., Kumari K.U. (2012). Post -harvest technology of Palmyra (Borassus flabellifer L.) present practices and scope. International conference on food processing by Omics group, India.

\section{How to cite this article:}

Soni Kumari, Ruby Rani, Samik Sengupta, AhmarAftab, Neha Kumari and Ankita Aman. 2020. Study of Genetic Variability of Palmyapalm on the Basis of Tree Morphology and Yield Parameters in Bihar. Int.J.Curr.Microbiol.App.Sci. 9(05): 2522-2528. doi: https://doi.org/10.20546/ijcmas.2020.905.289 